\title{
OCCUPATIONAL EXPOSURE TO INFRASONIC AND LOW FREQUENCY NOISE: ACTUAL PROBLEMS OF HYGIENIC STANDARDIZATION
}

\author{
Myshchenko I.', Nazarenko V. I.2, Stopa M.', Maslakiewicz M.'
}

'Accredited Laboratory of Occupational Health and Safety, Wroclaw University of Science and Technology, Wroclaw, Poland

\section{State Institution «Kundiiev Institute of Occupational Health of the National Academy of Medical Sciences of Ukraine», Kyiv, Ukraine}

Introduction. Infrasonic and low frequency noise (LFN) are environmental and occupational hazards, whose proportion continually increases. Commonly accepted hygienic standards and requirements to their measurements are absent and vary from country to country.

The purposes of the article are to conduct a literature review concerning current legislation of occupational exposure to LFN and infrasound; compare levels of LFN using frequency analysis in 1/3-octave bands in the ranges from 2 to $250 \mathrm{~Hz}$ at the workplaces and living settlements; analyze subjective complaints of people working/living in the areas of conducted measurements; propose an approach to the hygienic evaluation of LFN and infrasound.

Materials and methods of research. Analytical review of scientific publications was carried out using scientometric databases, periodicals and regulations. Sanitary and hygienic measurements of infrasound and LFN were conducted by the Octave 110A sound level meter in octave and $1 / 3$ octave bands with geometric mean frequencies in the range of $2-250 \mathrm{~Hz}$ at office premises, Academic Vernadskyi Antarctic Station,on the territory and premises of the residential area «Nova Darnytsia», on maritime transport of the DAT «Chernomorneftgaz» in accordance with current Ukrainian sanitary norms. A survey concerning subjective complaints about the parameters of physical factors (microclimate, artificial lighting, noise) was carried among 30 office workers of State Institution «Kundiiev IOH NAMS of Ukraine».

Results. Most of the published articles, dedicated to the impact of LFN and infrasound, consider results of measurements using A-weighting characteristics, which essentially reduces information about LFN. Our results show that LFN in the range $2-250 \mathrm{~Hz}$ is widespread in the industrial environment, in transport, residential areas, living premises. Despite the fact that noise levels measured using correction «A» do not exceed sanitary norms, up to $(44.0 \pm 3.7) \%$ of respondents complain about noise at the workplaces. The spread of noise increases with a prevalence of low frequency bands in its spectrum. So, an absorption of acoustic oscillations by building structures is $8 \mathrm{~dB}$ at frequency of $31.5 \mathrm{~Hz}$ and $14-16 \mathrm{~dB}$ at frequency of $250 \mathrm{~Hz}$. Acoustic oscillations in the range of $2-8 \mathrm{~Hz}$ at marine vessels are spread approximately by 1,000 times better than the sound perceived by the human ear.

Conclusions. Existing approaches to the problem of the assessment of occupational and habitual exposure to the infrasonic and LFN don't enable to substantiate generally accepted hygienic standards for these physical factors. National standards vary from country to country and differ from each other by established limits and measuring methods. Most of the published articles consider results of measurements using A-, C- and G-weighting characteristics, which do not provide objective information about spectral characteristics of the exposure hazard level. The authors suggest that the further identification of the problem should start from a common approach. The authors proposed the methodology of data acquisition measuring in the 1-500 Hz range using 1/3 octave bands, linear scale and linear RMS, Min and Max detector for the purpose of profound identification of low frequency sources and for objective analysis of human organism reactions to its exposure.

Key words: low-frequency noise, infrasound, occupational exposure, hygienic standardization

\section{Introduction}

Low-frequency noise (LFN) is a background noise whose proportion continually increases in modern urban environments. The World Health Organization
(WHO) recognized LFN as an environmental problem [1]. LFN and infrasound are also occupational hazards. Being generated by pumps, compressors, diesel engines, gas turbines, ventilation, heating 
and air conditioning systems and so on, they become the characteristics of various workplaces at airports, petrochemical plants, mines, transport, manufacturing enterprises, industrial control rooms, officelike areas etc.

Unlike the well-studied audible noise which can cause damage of hearing and various non-audible effects, LFN and infrasound remain underexplored. First attempts in their understanding were made 25-30 years ago. Usually, infrasound is defined as a noise in the range of $1-20 \mathrm{~Hz}$. Unfortunately, the upper and lower limits of LFN are still under discussion. Some European countries do not have national sanitary norms establishing admissible levels of infrasound and LFN. On the other hand, numerous studies confirm the negative impact of this noise on human beings [2-4]. Besides, available national standards and suggested methods of LFN and infrasound measurement are to some extent controversial.

The present article is aimed to:

- conduct a literature review concerning current legislation of occupational exposure to LFN and infrasound;

- compare levels of LFN using frequency analysis in $1 / 3$-octave bands in the ranges from 2 to $250 \mathrm{~Hz}$ at the workplaces (office premises, marine transport, Academic Vernadskyi Antarctic Station) and living settlements (based on our own results);

- analyze subjective complaints of people working/living in the areas of conducted measurements;

- propose an approach to the hygienic evaluation of LFN and infrasound.

\section{An overview of current sanitary legislation in some European countries for infrasound and LFN}

According to Leventhall G., LFN is considered the noise with dominating sound energy in the fre- quency range from about 10 to $200 \mathrm{~Hz}$ [2], which is a common conception. So far, these boundaries are not fixed. In scientific literature, LFN can also be defined in different limits: 10 to $250 \mathrm{~Hz}$ [3], from 20 to $250 \mathrm{~Hz}$ [4] and even from 20 to $500 \mathrm{~Hz}$ [5]. German standard DIN 45680:1997 [6] establishes lower and upper levels of LFN from 10 to $100 \mathrm{~Hz}$, Lithuanian - from 16 to $200 \mathrm{~Hz}$ [7]. Several examples of various limits suggested by different authors and national standards are shown in the Table 1.

There is a very indistinct boundary between infrasound and LFN which often causes confusion. ISO 7996:1995 [10] defines infrasound as noise with frequency within $1-20 \mathrm{~Hz}$, although earlier it was different. For instance, Polish norms PN 86/N01338 - out of order [11] had specified infrasound in the range from 2 to $50 \mathrm{~Hz}$. It is generally accepted that infrasound is nonaudible. However, this common assumption is incorrect because sound at the frequencies below $16 \mathrm{~Hz}$ is clearly audible if the level is high [12]. Sometimes, LFN and infrasound are noteven separated from each other, which also leads to misunderstanding for they cause a bit

\section{Iable 1}

Suggested upper and lower limits of LFN in scientific literature and national standards

\begin{tabular}{|l|c|}
\hline $\begin{array}{c}\text { Suggested } \\
\text { range, Hz }\end{array}$ & Source \\
\hline $10-200$ & Leventhall G. et al., 2003 [2] \\
\hline $10-250$ & $\begin{array}{r}\text { Pawlaczyk-Euszczyńska M. et al., } \\
2010 \text { [3] }\end{array}$ \\
\hline $20-250$ & Berglund B. et al., 1996 [4] \\
\hline $20-500$ & Alves-Pereira M. et al., 2007 [5] \\
\hline $10-100$ & DIN 45680:1997, 1997 [6] \\
\hline $16-200$ & HN 30:2016 [7] \\
\hline $10-160$ & $\begin{array}{c}\text { Danish Environmental Protection } \\
\text { Agency N 9/1997 [8] }\end{array}$ \\
\hline $31.5-200$ & SOSFS 1996:7/E [9] \\
\hline
\end{tabular}


different physiological effects in the human body, have dissimilar absorption and, correspondingly, the ability to spread through various mediums.

The variety of hygienic standards for limits of occupational exposure to infrasound in the range 2$20 \mathrm{~Hz}$ accepted in different countries are shown in the Table 2 .

The above mentioned International standard ISO 7996:1995 specifies G-weighting characteristics for the determination of infrasound. This characteristics, which was specially intended for infrasound, looks as a triangle with maximums at $20 \mathrm{~Hz}$ and minimums at 0.2 and $300 \mathrm{~Hz}$ correspondingly and differs from another weighting characteristics (Figure 1). Leventhall G. [2] underlines that «too much reliance on the G-weighting, ...may divert attention from problems at higher frequencies ...in the $30 \mathrm{~Hz}$ to $80 \mathrm{~Hz}$ range».

As it can be seen from the Table 2, the national standards vary from country to country. In some cases, admissible levels exceed hearing threshold ( $56.3 \mathrm{~dB}$ at the frequency $31.5 \mathrm{~Hz}$ ), established by ISO 226. Such huge difference can be explained by the application of different measuring methods. It is necessary to underline that hygienic assessment of LFN differs from high frequency noise analysis.
However, there is still no established guideline for LFN assessment at the workplaces. Some European countries use specific regulations on LFN control in apartments [17, 18]. Most of them are based on the frequency analysis in $1 / 3$-octave bands in the frequency ranges from 8 to $250 \mathrm{~Hz}$ using nominal A-weighting correction [19]. This approach is being highly criticized in scientific literature [20]. Alves-Pereira et al. compared the overall $\left(\mathrm{L}_{\mathrm{eq}}\right)$ values measured with A-weighting filter $(\mathrm{dB} / \mathrm{A})$ and without it $(\mathrm{dB} / \mathrm{Lin})$ in a cockpit of the Airbus-340 [21] and commuter train in motion [22]. The levels of noise in a train and in a cockpit measured in $\mathrm{dB} / \mathrm{A}$ were the same $(72.1 \mathrm{~dB} / \mathrm{A})$ but levels without A-weighting were $95.6 \mathrm{~dB} / \mathrm{Lin}$ and $83.2 \mathrm{~dB} /$ Lin correspondingly. In other words, people can hear the same level of noise in a train and a cockpit, but they are exposed to different amounts of acoustical energy. The point is, A-weighting filter is based on equal-loudness threshold and quite well simulates human's auditory thresholds. That's why it is primarily used for evaluating the risk of noise-induced hearing loss. Currently, we know that LFN has unique characteristics, quite different from the noise of higher pitch. It is reduced less by various shields, crosses

Table 2

Admissible levels of infrasound in normative documents of different countries

\begin{tabular}{|l|c|c|c|c|c|}
\hline \multicolumn{1}{|c|}{ Country/document } & \multicolumn{5}{c|}{ Frequency, [Hz] } \\
\cline { 2 - 6 } & $\mathbf{2}$ & $\mathbf{4}$ & $\mathbf{8}$ & $\mathbf{1 6}$ & $\mathbf{3 1 . 5}$ \\
\hline $\begin{array}{l}\text { Poland/PN-86/N-01338 - out of order [11] } \\
- \\
\text { - Performing basic functions in observations cabins and }\end{array}$ & - & 90 & 90 & 90 & 85 \\
\hline $\begin{array}{l}\text { remote control, or premises for precise work } \\
\text { design offices, research work, data handling }\end{array}$ & - & 85 & 85 & 85 & 80 \\
\hline Poland/PN-Z-01338:2010 [13] & \multicolumn{2}{|c|}{102} & \\
\hline Ukraine/_CH 3.3.6.037-99 [14] & 105 & 105 & 105 & 105 & $86-107^{*}$ \\
\hline Sweden/AFS2005:16 [15] & 130 & 118 & 106 & 94 & 61 \\
\hline Germany DIN 45680 [6] & - & - & 103 & 79 & 55.5 \\
\hline Denmark (at night) [2] & - & - & - & 76.7 & 59.4 \\
\hline
\end{tabular}

Note. *Depending on a type of work. 


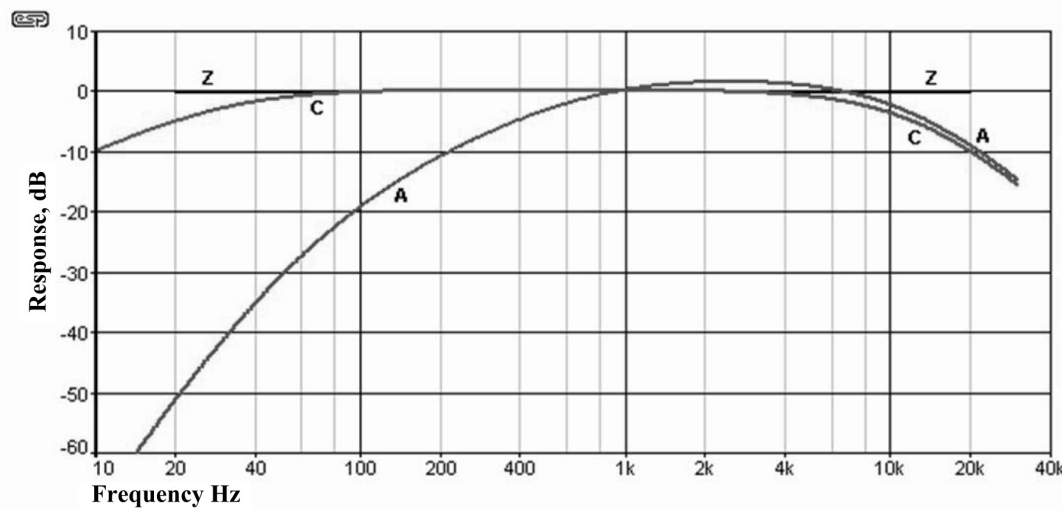

https://sound-au.com/articles/a-weighting.html

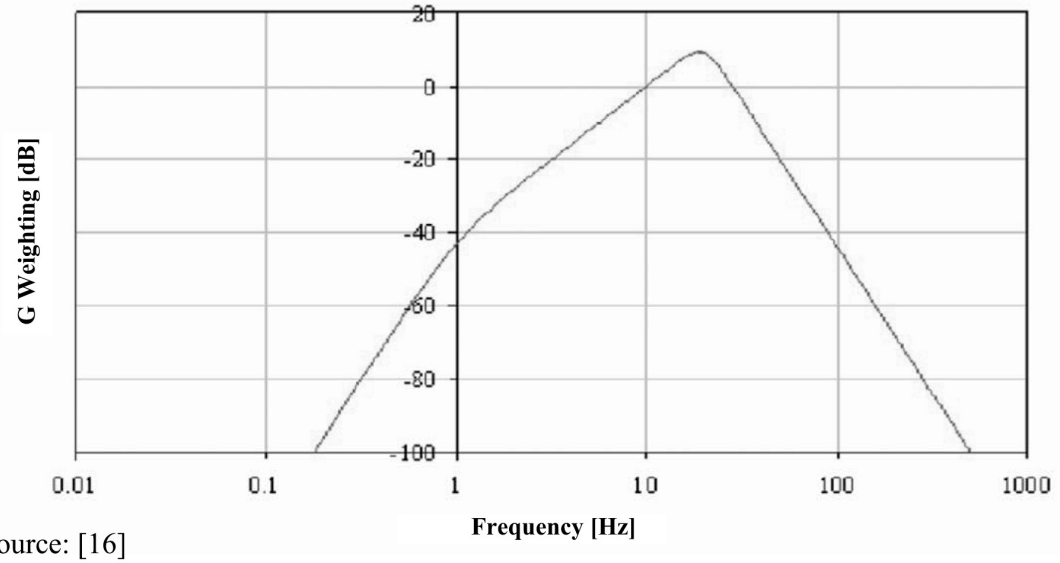

Figure 1. Frequency weighting curves $A, C, G$ and $Z$

greater distances, produces resonance in the human body (abdomen, chest, throat) etc. Moreover, ear protection devices are much less effective against it. So, application of A-weighted scale neglects sources below $50 \mathrm{~Hz}$ and does not consider physical peculiarities of LFN. According to the Canadian researchers studying aviation noise, it can lead to leaving out occupational health risks in the working population exposed to this occupational hazard [23]. The authors suggested using $\mathrm{C}$-weighted sound exposure level metric as indicator for LFN annoyance. This suggestion is based in the fact that $\mathrm{C}$-weighting level includes nearly all of the low frequency energy in a signal and, correspondingly, is more appropriate for LFN assessment.
Based on a literature review, Broner N. [24] recommends using $\mathrm{dB} / \mathrm{C}-\mathrm{dB} / \mathrm{A}$ difference of at least $20 \mathrm{~dB}$ to indicate the presence of $\mathrm{LFN}$ problem (as an indication of an unbalanced spectrum towards low frequencies). This method is inadequate for the identification of $\mathrm{LFN}$ at the workplaces with low noise levels $(45 \mathrm{~dB} / \mathrm{A}$ or less) considering the presence of self-generated noise of sound analyzers [16]. Therefore, there are no commonly established hygienic norms and standardized methods of measurement of LFN and infrasound, so their criteria vary from country to country [25]. WHO [26] admits that using of A-weighted scale is unfitted to measurements of noise levels with prevalence of low frequencies, but it does not suggest any alternative. Additionally, 
some industrial and natural sources may generate impulse-like low frequency noise. It means that commonly used SLOW time constant is not enough for the comprehensive analysis.

\section{Materials and methods of research}

Sanitary and hygienic measurements of infrasound and LFN were conducted by the Octave $110 \mathrm{~A}$ sound level meter in octave and 1/3 octave bands with geometric mean frequencies in the range of $2-250 \mathrm{~Hz}$ at office premises (State Institution «Kundiiev IOH NAMS of Ukraine» (Kyiv, 2020), Academic Vernadskyi Antarctic Station (Antarctic Peninsula, 2004)), on the territory and premises of the residential area «Nova Darnytsia» (Kyiv), on maritime transport of the DAT «Chernomorneftgaz» (2012-2013). Hygienic assessment of sound pressure levels was conducted in accordance with current Ukrainian sanitary norms: SSN 3.3.6.037-99 «Sanitary Norms of Industrial Noise, Ultrasound and Infrasound» and Order of the Ministry of Health of Ukraine dated 22.02.2019 No. 463»
State Sanitary Norms of permissible noise levels in residential and public buildings and in residential areas». A survey concerning subjective complaints on the parameters of physical factors (microclimate, artificiallighting, noise) was carried among 30 office workers of State Institution «Kundiiev IOH NAMS of Ukraine».

\section{Research results and their discussion}

According to the data of instrumental measurements, the levels of sound and sound pressure level sat office premises with and without air conditioning systems (Figure 2) meet the requirements of sanitary norms. Nevertheless, results of the survey, conducted among workers show that $(44.0 \pm$ $3.7) \%$ respondents complain about the noise level at the workplaces. Considering the fact, that parameters of acoustic load at the workplaces did not exceed admissible level in $65 \mathrm{~dB} / \mathrm{A}$, this fact needs further research in the terms of its irritating and interfering action on the human organism and the ability to concentrate at work.

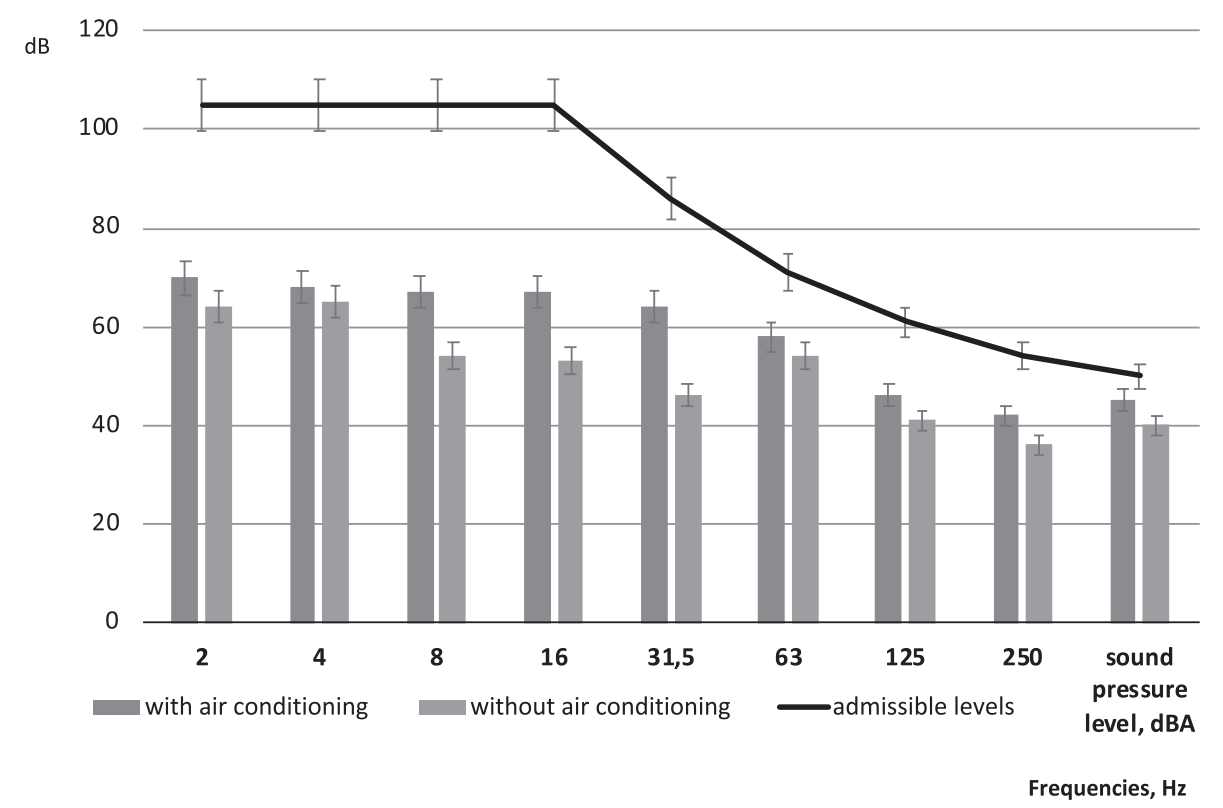

Figure 2. Comparison of admissible sound pressure level and measured at the offices of State Institution «Kundiiev IOH NAMS of Ukraine» 
During scientific expedition to the Antarctic Peninsula, the levels of LFN were measured at the diesel room and living premises of Academic Vernadskyi Antarctic Station. A main building with scientific laboratory and living rooms was located $15 \mathrm{~m}$ from the diesel room, generating LFN by three diesel Volvo engines. Our results show, that the absorption of the noise by the walls of the premises and double-glazed windows at the frequency $25 \mathrm{~Hz}$ was only $9 \mathrm{~dB}$ and at the frequency $80 \mathrm{~Hz}-$ $25 \mathrm{~dB}$ (Table 3).

Sound pressure levels at these frequencies do not meet sanitary standards for living premises at night time. At the higher frequencies (above $160 \mathrm{~Hz}$ ) absorption by building structures was much better, making up 47-61 dB.

Various kinds of diesel engines produce infrasonic and LFN in the range of $2-63 \mathrm{~Hz}$ in marine transport and affect crew of the ship during performing their duties and at the rest, evidenced by the study of working conditions at the vessels of the DAT «Chernomorneftgaz» (Table 4). It was found that the main sources of noise $(31.5-8000 \mathrm{~Hz})$ and infrasound $(2-16 \mathrm{~Hz})$ at the ships of I-III categories are diesel generators with power from 50 to $2500 \mathrm{~kW}$. This equipment works constantly, not only when the ship is going to sea, but also when it is at a standstill, in a mode of lower power. At the same time, the maximum noise levels can reach $109 \mathrm{~dB} /$ Ain the mode of putting the diesel into operation, and 112-115 dB/Lin (infrasound range). The equivalent noise level $\left(\mathrm{L}_{\mathrm{eq}}\right)$ in the engine room (mechanics, electricians and electromechanical technicians of all types ) is $90-98 \mathrm{~dB} / \mathrm{A}$. For sailors and boatswains working on the deck and in the service rooms, noise load with levels $84-92 \mathrm{~dB} /$ Ais formed mainly due to the usage of pneumatic and electric vibrating tools during repair actions. It should be noted that most specialists perform activities inside the premises with different levels of fluctuating or intermittent noise. At the workplaces of the management and auxiliary personnel, the noise load was only $62-67 \mathrm{~dB} / \mathrm{A}$ and exceeded the permissible level only at $25-40 \%$ of total workplaces. However, in all these rooms there was a significant infrasound level $(88-97 \mathrm{~dB} /$ Lin $)$ with the maximum acoustic energy at the frequencies of $2-4 \mathrm{~Hz}$.

Measurements of infrasound levels in the main areas of the ship showed that in the cabins it exceeds the threshold of adverse effects (interfering, irritating action) for living premises by $9-15 \mathrm{~dB} /$ Lin according to the literature data (Izmerov N. F. et al., 1997). This fact indicates that the crew does not have adequate conditions to rest and recover. Infrasound in the range $2-8 \mathrm{~Hz}$ is absorbed by the

LFN measurements in the premises of the diesel and living premises

Table 3 of the Academic Vernadskyi Antarctic Station

\begin{tabular}{|c|c|c|c|c|c|c|c|c|c|c|c|}
\hline \multirow{2}{*}{ Place of measurement } & \multicolumn{11}{|c|}{$\begin{array}{l}\text { Sound pressure levels }(\mathrm{dB}) \text { in } 1 / 3 \text {-octave bands with geometric } \\
\text { mean frequencies, }[\mathrm{Hz}]\end{array}$} \\
\hline & 25 & 31,5 & 40 & 50 & 63 & 80 & 100 & 125 & 160 & 200 & 250 \\
\hline Diesel room & 79 & 66 & 73 & 74 & 77 & 93 & 78 & 86 & $89^{*}$ & $98 *$ & $94^{*}$ \\
\hline Admissible level* & \multicolumn{3}{|l|}{107} & \multicolumn{3}{|c|}{95} & \multicolumn{3}{|l|}{87} & \multicolumn{2}{|l|}{82} \\
\hline Living premises & $68 *$ & 53 & 48 & 41 & 48 & $68^{*}$ & 41 & 40 & 42 & 33 & 32 \\
\hline $\begin{array}{l}\text { Admissible level** } \\
\text { day/night }\end{array}$ & \multicolumn{3}{|c|}{$68 / 63$} & \multicolumn{3}{|c|}{$57 / 50$} & \multicolumn{3}{|c|}{$48 / 40$} & \multicolumn{2}{|c|}{$41 / 33$} \\
\hline
\end{tabular}

Note. *State Sanitary Norms 3.3.6.037-99, **State Sanitary NormsNr 463-2019. 
Comparison of infrasound level in the main areas of ship to hygienic requirements

\begin{tabular}{|l|c|c|c|c|c|c|}
\hline \multirow{2}{*}{ Place of measurement } & \multicolumn{4}{c|}{$\begin{array}{c}\text { Sound pressure level }(\mathbf{d B}) \text { in } \mathbf{1 / 3} \text { octave bands at } \\
\text { geometric mean frequencies, } \mathbf{M} \pm \boldsymbol{\delta},[\mathbf{d B}]\end{array}$} & \multicolumn{2}{c|}{$\begin{array}{c}\text { General level of infra- } \\
\text { sound/sound, [dB] }\end{array}$} \\
\cline { 2 - 7 } & $\mathbf{2}$ & $\mathbf{4}$ & $\mathbf{8}$ & $\mathbf{1 6}$ & dB Lin & dBA \\
\hline Engine rooms & $97 \pm 2.8$ & $87 \pm 2.5$ & $84 \pm 3.1$ & $93 \pm 4.2$ & $103 \pm 3.4$ & $97 \pm 4.2$ \\
\hline Admissible levels* & 105 & 105 & 105 & 105 & 110 & 80 \\
\hline Central control panel, office & $87 \pm 4.0$ & $79 \pm 3.5$ & $75 \pm 3.6$ & $79 \pm 3.1$ & $92 \pm 4.1$ & $68 \pm 4.6$ \\
\hline Admissible levels** & 95 & 90 & 85 & 80 & 95 & - \\
\hline Cabin & $84 \pm 3.2$ & $77 \pm 3.0$ & $72 \pm 2.8$ & $75 \pm 3.3$ & $87 \pm 3.6$ & $57 \pm 3.4$ \\
\hline Admissible levels*** & 75 & 70 & 65 & 60 & 75 & - \\
\hline
\end{tabular}

Note. *State Sanitary Norms 3.3.6.037-99, **Izmerov N. F. (for the work, requiring emotional and intellectual strain),

***Izmerov N. F. (for the living premises).

vessel constructions only by $10-12 \mathrm{~dB}$. At the same time, noise levels are reduced by $36-$ $44 \mathrm{dBA}$. This shows that infrasound in the range of $2-8 \mathrm{~Hz}$ penetrates through the premises of sea vessels in about 1000 times better than the audible sound, perceived by human ears.

People are exposed to infrasonic and LFN not only at work, but also in residential areas. The main sources of these physical factors in settlements are various installations inside the buildings (ventilation and climatization systems) andsounds from the outside of the buildings (primarily transport). Measurements conducted in residential area «Nova Darnytsia» (Kyiv) showed exceeding of admissible levels of noise in the range of 31.5$250 \mathrm{~Hz}$ during the day and night (Figure 3).

As it can be seen, exceeding of the sound pressure levels is up to $16 \mathrm{~dB}$ comparing to existing sanitary norms, especially at night. Acoustic oscillations are absorbed by building structuresby $8 \mathrm{~dB}$ at the frequency of $31.5 \mathrm{~Hz}$ during the day ( 8 AM-10 PM) and night (10 PM-8 AM) and by $14-16 \mathrm{~dB}$ at the frequency of $250 \mathrm{~Hz}$. Unfortunately, absence of standards regulating admissible level of sound pressure in the range $2-31.5 \mathrm{~Hz}$ make hygienic assessment impossible. On the other hand, presence of numerous subjective complaints on the noise level and its irritative effect at the workplaces and residential areas rises a significant hygienic problem concerning establishing safe levels of exposure to infrasound and LFN. Solution of this task should include collection of comprehensive bases of measurements of infrasound and LFN at different workplaces, studying of dose-effect relationship which is based not only on subjective complaints, but analysis of objective physiological changes caused by such exposure (hearing thresholds, heart rate variability), investigation of individual sensitivity to noise etc. Such an approach will allow to substantiate hygienic standards and develop effective collective and individual preventive measures.

\section{Conclusions}

1. Existing approaches to the problem of assessment of occupational and habitual exposure to the infrasonic and LFN haven't allowed yet to substantiate generally accepted hygienic standards for these physical factors. National standards vary from country to country and differ from each other by established limits and measuring methods. Most of the published articles 


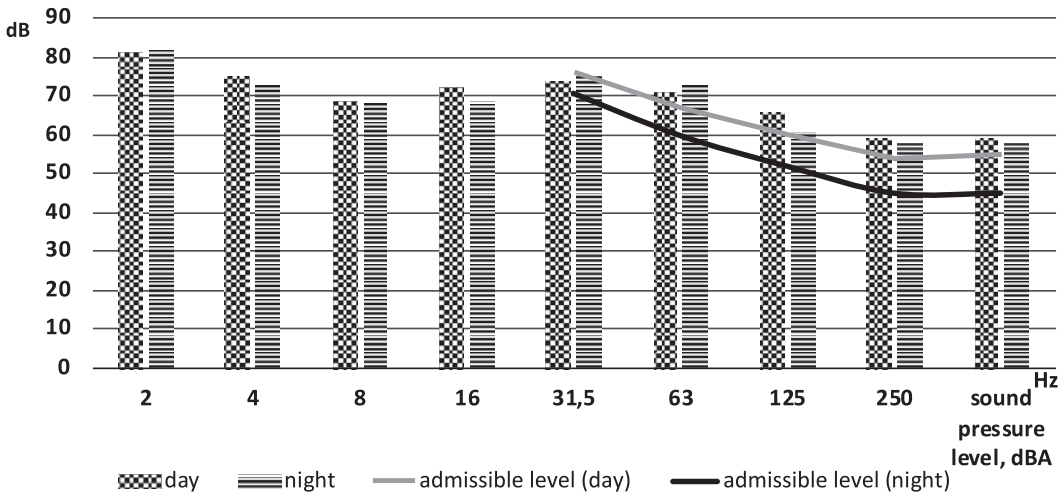

A

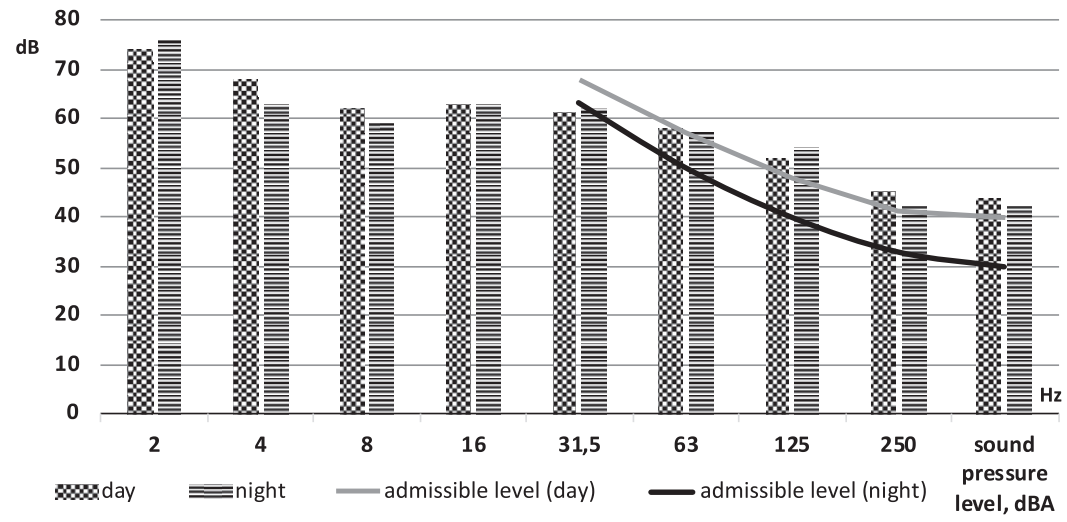

B

Figure 3. Sound pressure levels in octave bands with geometric mean frequencies measured at the residential area «Nova Darnitsia» (Kyiv) in the near vicinity of the house $(A)$ and in the living premises $(B)$ in comparison to admissible levels

consider results of measurements using A-, Cand G-weighting characteristics, which do not provide objective information about spectral characteristics of the exposure hazard level.

2. Based on the literature review and the analysis of obtained results, the authors suggest that the further identification of the problem should start from a common approach.

\section{References}

1. World Health Organization. Environmental noise guidelines for the European region. 2018:160. Available at: https://www.euro.who.int/en/publications/abstracts/ environmental-noise-guidelines-for-the-european-region-2018.
3. The methodology of data acquisition brought into practice by our research team is measuring in the $1-500 \mathrm{~Hz}$ range using $1 / 3$ octave bands, linear scale and linear RMS, Min and Max detector for the purpose of profound identification of low frequency sources and for objective analysis of human organism reactions to its exposure.

2. Leventhall, G., Pelmear, P. and Benton, S. (2003), A review of published research on low frequency noise and its effects, UK Department for Environment, Food and Rural Affairs, https://doi.org/EPG1/2/50.

3. Pawlaczyk-Łuszczyńska, M. (2010), Ocena uciażliwości hałasu niskoczęstotliwościowego w środowisku 
pracy oraz jego wpływ na funkcje umysłowe. Rozprawa habilitacyjna wyd. IMP Łódź.

4. Berglund, B., Hassmen, P., Job, R. F. (1996), "Sources and effects of low-frequency noise», J Acoust. Soc. Am., Vol. 99, No. 5, pp. 2985-3002, https://doi.org/ $10.1121 / 1.414863$.

5. Alves-Pereira, M., Castelo Branco, N. (2007), "Vibroacoustic disease: Biological effects of infrasound and low-frequency noise explained by mechanotransduction cellular signaling", Progress in Biophysics and Molecular Biology, Vol. 93, No. 1-3, pp. 256-279, https://doi.org/10.1016/j.pbiomolbio.2006.07.011.

6. DIN 45680:1997 Messung und Bewertungtieffrequenter Gerauschimmissionen in der Nachbarshaft (Measurement and assessment of low-frequency noise immissions in the neighbourhood).

7. Hygiene norm HN 30:2016, Infrasound and low frequency sounds: Limit values for residential and public buildings, Minister of Health of the Republic of Lithuania.

8. Low frequency noise, infrasound and vibration in the environment. Information from the Danish Environmental Protection Agency no. 9/1997 (State Sanitary Norms, Denmark).

9. SOSFS 1996:7/E: Indoor Noise and High Sound Levels, Socialstyrelsen, Sverige, 15 Maj 1996 (State Sanitary Norms, Sweden).

10. ISO 7996:1995 Acoustics. Frequency. Weighting characteristics for infrasound measurements.

11. PN-N-01338:1986 Hałas infradźwiękowy. Dopuszczalne wartości poziomów ciśnienia akustycznego na stanowiskach pracy u ogólne wymagania dotyczace wykonywania pomiarów (wersja polska, Poland).

12. Leventhall, G. (2006), "Infrasound from wind turbines - fact, fiction or deception", Canadian Acoustic, Vol. 34, No. 2, pp. 29-36.

13. PN-Z-01338:2010 Akustyka - Pomiar i ocena hałasu infradźwiękowego na stanowiskach pracy (wersja polska, Poland).

14. SSN 3.3.6.037-99 State sanitary norms occupational noise, ultrasounf and infrasound [DSN 3.3.6.03799 Sanitarni normi virobnichogo shumu, ul'trazvuku ta infrazvuku]. Available at: https://zakon.rada.gov.ua/ rada/show/va037282-99\#Text.

15. AFS 2005:16 Arbetsmiljöverkets föreskrifter om buller samt allmänna råd om tillämpningen av föreskrifterna (The Swedish Work Environment Authority's regulations on noise and general advice on the application of the regulations). Available at: https://www.av. se/globalassets / filer/publikationer / foreskrifter / buller-foreskrifter-afs2005-16.pdf.
16. Downey, G., Parnell, J. (2017), Assessing low frequency noise from industry - a practical approach. $12^{\text {th }}$ ICBEN Congress on Noise as a Public Health Problem.

17. Jakobsen, J. (2000), Danish Guidelines on Environmental Low Frequency Noise, Infrasound and Vibration, in: Moller H. and Lydolf M., eds. Proceedings of the $9^{\text {th }}$ International Meeting on Low Frequency Noise \& Vibration, $17^{\text {th }}-19^{\text {th }}$ May 2000, Aalborg, Denmark, pp. 57-64.

18. Mirowska, M. (2001), "Evaluation of Lowfrequency Noise in Dwellings. New Polish Recommendations", Journal of Low Frequency Noise, Vibration and Active Control, Vol. 20, No. 2, pp. 67-74, https://doi. org/ 10.1260/0263092011493163.

19. Pawlaczyk-Łuszczyńska, M., Szymczak, W., Dudarewicz, A., liwińska-Kowalska, M. (2006), "Proposed criteria for assessing low frequency noise annoyance in occupational settings", Int. J. Occup. Med. Environ Health, Vol. 19, No. 3, pp. 185-197, https://doi. org/ 10.2478/v10001-006-0022-9.

20. Alves-pereira, M., Motylewski, J., Kotlicka, E., Branco, N. (2005), "Low frequency noise legislation", 12th International Congress on Sound and Vibration, ICSV, Vol. 2, pp. 1478-1485.

21. Alves-Pereira, M., Castelo Branco, M., Motylewski, J. et al. (2001), Airflow-induced infrasound in commercial aircraft, In: Proceedings of the Internoise, The Hague, Holland, pp. 1011-1014.

22. Alves-Pereira, M., Joanaz de Melo, J., Castelo Branco, N. (2001), Low frequency noise in trains, In: Proceedings of Internoise, Prague, Czech Republic, No. 643, 5 p.

23. Hodgdon, K., Atchley, A., Bemhard, R. (2007), Low frequency noise study, Final report. PartnerCOE-2007- 001. 2007:105 available at: https://rosap. ntl.bts.gov/view/dot/26137/Print.

24. Broner, N. (2010), "A simple criterion for low frequency noise emission assessment", Journal of low frequency noise, vibration and active control, Vol. 29, No. 1, pp. 1-13, https://doi.org/10.1260/02630923.29.1.1.

25. Pawlas, K., Pawlas, N., Boroń, M. et al. (2013), "Przegląd kryteriów oceny infradźwięków i hałasu niskoczęstotliwościowego $\mathrm{w}$ środowisku zawodowym i pozazawodowym", [Infrasound and low frequency noise assessment at workplaces and environment - review of criteria], Environmental Medicine, Vol. 16, No. 1, pp. 82-89.

26. Beglung, B., Lindvall, T. (1999), Guidelines for community noise. WHO. 
ORCID ID of co-authors and their contribution to the preparation and writing of the article:

Myshchenko I. (ORCID ID 0000-0003-0872-9499) - the aim setting, planning of the researches, review of literature data, text writing and article design, analysis of results, conclusions;

Nazarenko $V$. (ORCID ID 0000-0002-5238-4312) - conducting the questionnaire surveys, instrumental measurements;

Stopa M. (ORCID ID 0000-0001-7455-8312) - determination of the direction and the tasks of the researches, significance of the problem, discussion of results;

Maslakiewicz M. (ORCID ID 0000-0001-5325-0634) - literature review, work on graphic and tabular material, discussion of results.

Information on the source of funding for the study: the scientific researches was carried out within the frames of Research Programs «Study of the Combined Effects of Electromagnetic Fields of Industrial Frequency, Noise, Microclimate (to the Problem of Hygienic Standardization)», No. of state registration: 0104U003074; «Development of Recommendations for Measures to Optimize Working Conditions in Office Premises», No. of state registration: 0113U001441; «Substantiation of Sanitary and Hygienic Recommendations for Improving Working Conditions and Lighting When Using LED Light Sources in Office Premises (experimental studies)», No. of state registration: $0116 \mathrm{U} 000502$.

Received: November 11, 2021

Accepted for publication: December 9, 2021

Contact person: Myshchenko Iryna, PhD in Biology, Accredited Laboratory of Occupational Health and Safety, Wroclaw University of Science and Technology, naGrobli 13, Wroclaw, 50-421, Poland. Tel.: + 48731250345. E-mail: iryna.myshchenko@pwr.edu.pl 